Sains Malaysiana 50(7)(2021): 1857-1870

http://doi.org/10.17576/jsm-2021-5007-03

\title{
Geological Effects on Water Quality: A Review of Issues and Challenges in Malaysia
}

(Kesan Geologi terhadap Kualiti Air: Suatu Ulasan Berkenaan Isu dan Cabaran di Malaysia)

\section{Terfa E. Garba*, Reena L. Richard, Nor Ezzawanis A. Thani, Mohamad Azlan A. Majid, Mutari Lawal} \& NURA A. YELWA

\section{ABSTRACT}

Malaysian source of water for household and industrial use is derived mainly from surface sources. The increasing demand for quality water for household consumption and industrial use has posed a great challenge to the otherwise abundant but scarce natural resources. This paper examines the important challenges associated with the deteriorating water quality in Peninsular Malaysia. Quality water enhances one's good health. Therefore, evaluating health risk as a result of heavy metals introduction through drinking water from various geological activities like the ex-mining ponds in Klang Valley is worthy to note. Heavy metals which are one of the sources of contaminants, due to their solubility are transported from their source (mining, agricultural, and industrial) to groundwater. There is a linkage between land-use change (activities) such as logging, agriculture, urbanization, mining, and industrial activities as a potential source of contaminants, this is further conflated by the hydrogeology of the areas which show a shallow aquifer system predominantly associated with alluvial and carbonate. Also, microbial contamination had affected water sources. Given that more of the aquifer systems in Peninsular Malaysia are shallow, this makes it very easy for groundwater sources around Malaysia to be contaminated. The industrialisation and urbanisation in Malaysia, as well as the growing population, posed a great challenge to water quality. This paper highlights the key challenges and possible solutions to water quality management in Malaysia.

Keywords: Geological; hydrogeology; microbial contamination; Peninsular Malaysia; water quality

\section{ABSTRAK}

Punca air Malaysia untuk kegunaan isi rumah dan perindustrian berasal terutamanya daripada punca permukaan. Peningkatan permintaan air yang berkualiti untuk penggunaan isi rumah dan penggunaan industri telah menimbulkan tentangan yang besar bagi punca semula jadi yang semakin berkurang. Makalah ini mengkaji cabaran penting yang berkaitan dengan kemerosotan kualiti air di Semenanjung Malaysia. Kualiti air meningkatkan kesihatan seseorang. Oleh itu, menilai risiko kesihatan sebagai hasil pengenalan logam berat melalui air minuman daripada pelbagai aktiviti geologi seperti kolam bekas perlombongan di Lembah Klang patut diperhatikan. Logam berat yang merupakan salah satu punca bahan cemar, kerana kelarutannya diangkut daripada puncanya (perlombongan, pertanian dan perindustrian) ke air bawah tanah. Terdapat kaitan antara perubahan penggunaan tanah (aktiviti) seperti pembalakan, pertanian, pembandaran, perlombongan dan aktiviti industri sebagai punca pencemaran yang berpotensi, ini selanjutnya digabungkan oleh hidrogeologi kawasan yang menunjukkan sistem akuifer cetek terutama terkait dengan aluvium dan karbonat. Juga, pencemaran mikrob mempengaruhi punca air. Disebabkan banyak sistem akuifer di Semenanjung Malaysia cetek, ini menjadikan punca air bawah tanah di sekitar Malaysia mudah tercemar. Perindustrian dan pembandaran di Malaysia, serta pertambahan penduduk, menimbulkan cabaran besar terhadap kualiti air. Makalah ini menyoroti cabaran utama dan kemungkinan penyelesaian terhadap pengurusan kualiti air di Malaysia.

Kata kunci: Geologi; hidrogeologi; kualiti air; pencemaran mikrob; Semenanjung Malaysia 


\section{INTRODUCTION}

Malaysia derived its water mainly from surface sources (Hafizi et al. 2018). Groundwater seems not to be a major source but creates a complementary constituent activated only around districts that surface sources are readily not available. In recent times, groundwater as a source of water has grown in its importance, given the high demand for surface water which has outstripped its availability, hence, the need to objectively evaluate the geological structure of Peninsular Malaysia as well as the impact on the quality of water.

This paper takes into consideration of various research works on water quality in Malaysia as well as the challenges related to water quality, given the geology of the region. The determination of groundwater quality around Peninsular, the description of the problems associated with the deteriorating quality of water as well as possible solutions to these issues in Malaysia as opined by Chappell et al. (2017), Chong and Tan (1986), Koki et al. (2017), Narany et al. (2014), Park et al. (2011), Srebotnjak et al. (2012), and Sultan and Shazili (2009).

\section{HYDROGEOLOGICAL SETTINGS OF PENINSULAR MALAYSIA}

Groundwater potentials of Peninsular Malaysia discoursed in relations to rock categories (Chong \& Tan 1986); the groundwater prospect of the Peninsular further grouped into four main categories (Figure 1).

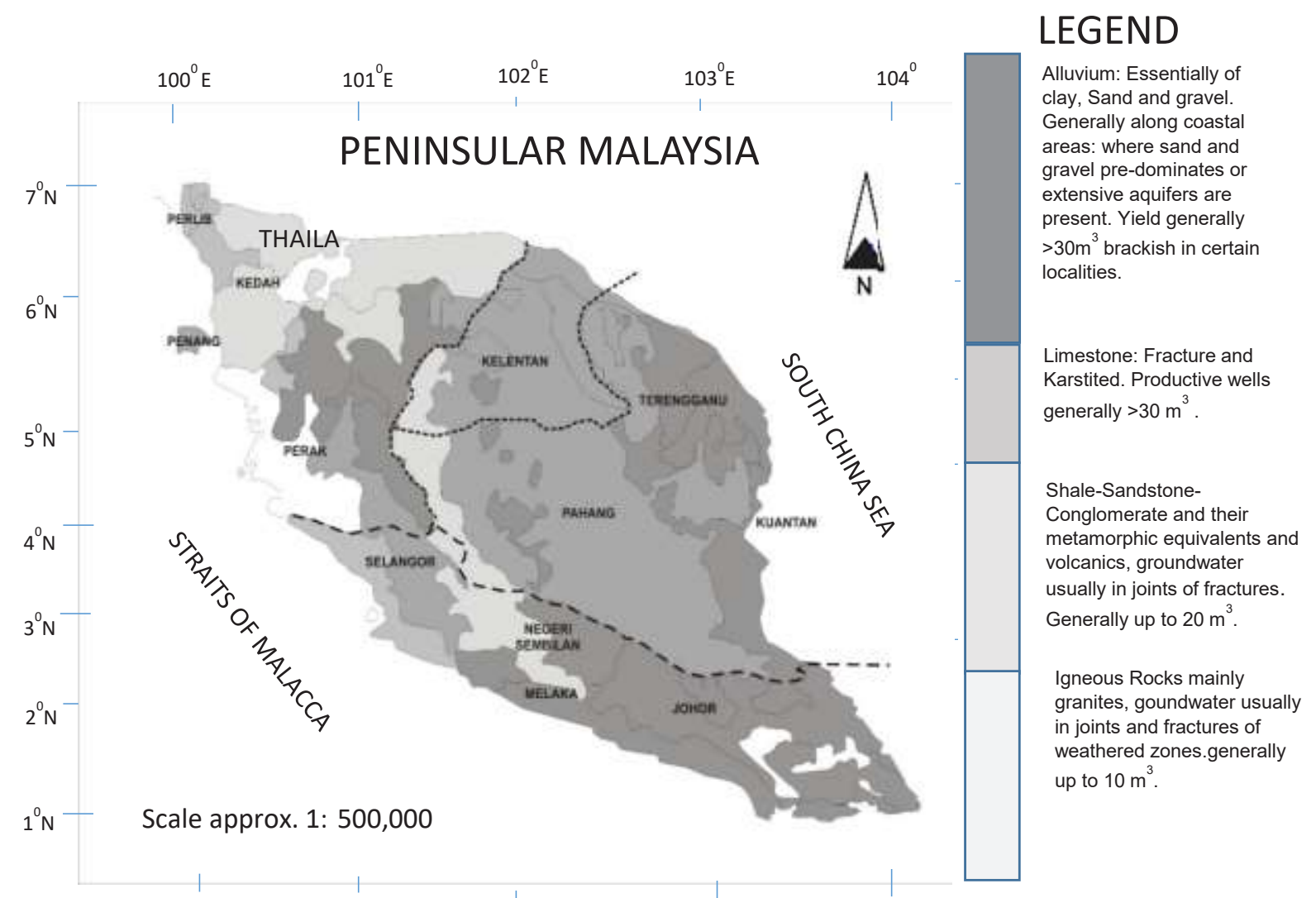

FIGURE 1. Simplified hydrogeological map of Peninsular Malaysia redrawn after Chong and Tan (1986) 
The quaternary alluvium holds the most promising aquifer system within the Peninsular; towards the east coast, alluvial aquifers show the highest potential for groundwater development (Chong \& Tan 1986). Besides the quaternary alluvium, the carbonate rocks also hold important aquifer systems, although their distributions restricted to Perlis, North Kedah, Perak, Selangor as well as several parts of Kelantan.

Whereas, sedimentary and volcanic rocks underlie the rest of the Peninsular. Groundwater potentials of these areas are limited. The concentration is more of a surface source. Given the variability of surface water and groundwater in some parts of Malaysia due to none define aquifer system or the absence of such. The good knowledge of the geology of Malaysia, as it relates to hydrology and consequently, the management of all the available water sources will do well to resolve the issues surrounding water quality in Malaysia (Chen et al. 2010; Garcia-Diaz 2011; Kurunc et al. 2011, 2016; Lawniczak et al. 2016; Manassaram et. 2007; Nur Hayati 2011; Powlson et al. 2008; Shamshuddin et al. 2013; Sheikhy Narany et al. 2013).

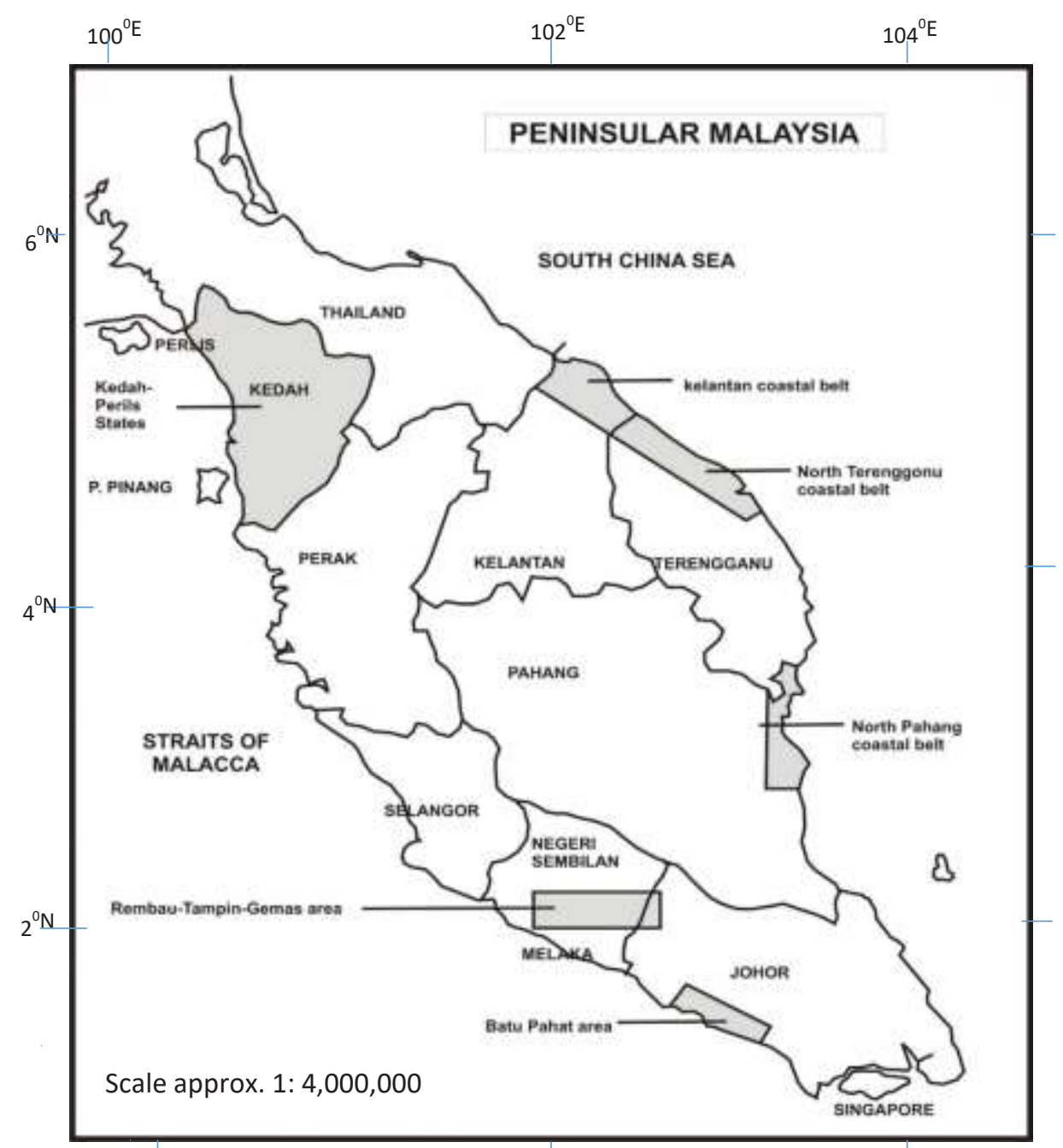

FIGURE 2. Areas where detailed hydrogeological investigations have been undertaken since 1975, redrawn after Chong and Tan (1986) 
Malaysian hydrogeological map (Figure 2) is a useful tool in the planning and implementation of hydrogeological programs with urbanisation taking centre stage and as the growing need for clean water increases.

\section{STATUS OF WATER QUALITY IN MALAYSIA}

Regardless of developed and developing countries, most of the nations are facing difficulties in obtaining clean water. Malaysia as a nation is not an exception; located in the Southeast Asian region, is blessed not only with its flora and fauna, but also rich in its water resources. The country, divided by the South China Sea, consisted of Peninsular Malaysia and East Malaysia (Sabah and Sarawak) that includes nearly 200 river systems throughout the country (Mohamad et al. 2010). With dry and wet season occurring throughout the year, there is no doubt that water scarcity is considered rare. However, climate change has had a significant effect on a dry spell and wet season (Deni et al. 2010; Tang 2019), decreasing the interval period between dry spell and wet season which has resulted in excessive rainfall at some point leading to flooding in some part of the country (Kabiri et al. 2015; Mayowa et al. 2015).

Among the problems of water supply in Malaysia are due to the non-uniform rainfall distribution throughout the year, lack of supply than the demand in city areas and polluted water (Abdullah \& Zaki 2013). However, water pollution and its deterioration had caused a tremendous impact on our water system. Various factors had contributed to the declining of water quality, hence, affecting the ecosystem surrounding the water bodies. The pollution in our water sources considerably emerged due to urbanisation, expansion of economic developments, increased in the human population as well as ineffective water management (Afroz \& Rahman 2017; Afroz et al. 2014; Fulazzaky et al. 2010; Huang et al. 2015; Muyibi et al. 2008a; Naubi et al. 2016). Nonetheless, local authorities, private sectors, government agencies and nongovernmental organisations (NGOs) had joined forces to address the alarming issue (Chan 2012; Evans et al. 2012; Hezri \& Nordin Hassan 2006; Ismail et al. 2013; Tan \& Mokhtar 2009; Weng 2005).

Good water quality indeed ensures the good health of each individual. Moreover, the usage of contaminated water may cause various health problems like typhoid fever, cholera, poor blood circulation, skin lesions, vomiting as well as damage to the nervous system (Rafia \& Ataur 2017). Concerning the increased population growth in Malaysia, the mandate for the built-up area, agricultural actions, as well as water resources, are also increasing. These escalating demands led to the 'Land Use Land Cover' (LULC) changes (Hua 2017). LULC changes in watershed areas for urbanisation and deforestation are detrimental to water quality. Salinity pollution was proven to cause by the usage of pesticides in agriculture, while sewage from farms contributed to $E$. coli and total coliforms (Hua 2017). Contamination also arouse from seawater intrusion (Aris \& Mohd Isa 2012; Baharuddin et al. 2013; Pujari \& Soni 2008; Samsudin et al. 2008), the failure of STP is another source of contamination (Al-Odaini et al. 2013; Isobe et al. 2002).

Organic contaminants derived from industrial and domestic sources associated with wastewater treatment plants also constitute sources of contaminant (Omar et al. 2018). In a study carried out in Sungai Johor Basin, among the likely contamination sources are from the mineral component; industrial activity, agriculture, sewage, and livestock manures (Mohd. Saiful et al. 2017). Logging activities have also been well-thought-out as a contributing factor to water and sediment quality depletion (Camara et al. 2019; Ling et al. 2016; Rak et al. 2011; Zaiha et al. 2015).

Various methods have been used to assess the water quality of rivers in Malaysia, including chemometrics (Gazzaz et al. 2012a; Juahir et al. 2011), observational studies on diatom communities (Wan Maznah \& Mansor 2002), and artificial neural network (ANN) modelling (Gazzaz et al. 2012b), among others. The common parameters measured in river pollution studies include the six parameters commonly used in the calculation of the Water Quality Indexes (WQI), namely Dissolved Oxygen (DO), Biochemical Oxygen Demand (BOD), Chemical Oxygen Demand (COD), Ammoniacal Nitrogen (AN), Total Suspended Solid (TSS), Total Dissolved Solids (TDS) and $\mathrm{pH}$. Besides, other parameters such as Polycyclic Aromatic Hydrocarbons (PAHs) (Keshavarzifard et al. 2014) as well as Organochlorine and Organopesticides (Leong et al. 2007) were also measured and studied in assessing the river water quality. The traditional method of analysis is dependent on datasets that involve a huge amount of unknown, narrowing the unknown to a nearexact require an advance analysis with its objectivity being water quality (Ahmed et al. 2019; Palani et al. 2008). Some researcher also incorporated the use of remote sensing imagery to detect the degree of LULC changes related to the depletion of water quality (Hua 2017). Nonetheless, LULC contributed to a generalised impression of the river water quality in an urban area (Vishnu Radhan et al. 2017). In their review, Camara et al. (2019) classified the various sources of pollution to point source and non-point sources. The non-point sources 
are associated with land management, geological and hydrogeological processes which are subject to change daily or annually. Significantly land use has affected the water quality as outlined in Camara's review. However, these activities even with the knowledge of its effect on water quality continue unmitigated.

The various standardized method that aligns with American Public Health Association (APHA) as it relates to water quality, the measurement methods involved in situ analysis and laboratory analysis (Hua 2017; Ling et al. 2016). Ex-situ analyses were sometimes applied (Ling et al. 2016). The water quality was analysed for it's in situ ( $\mathrm{pH}$, temperature, salinity, turbidity) or ex-situ parameters (total suspended solids, chemical oxygen demand), as well as biological parameters (Escherichia coliform and total coliform). The analysis results were then subjected to cluster statistical analysis (CA), principal component analysis (PCA), and canonical correlation analysis (CCA) to further identify the most significant factors of water depletion such as industrial activities, logging, and agriculture.

Watershed area selected for water change detection study is an area with various disturbances such as densely urbanised, subjected to commercial timber harvesting, subsistence farming or surrounded by crop cultivations (Hua 2017; Ling et al. 2016; Mohd Saiful et al. 2017; VishnuRadhan et al. 2017). Some authors chose to work only on the resultant information retrieved from the Department of Environment (DOE) (Mohd Saiful et al. 2017) while some other authors chose to work on both primary data collected from fields and the secondary data (Hua 2017). Secondary data were subjected to various statistical analyses such as Principal Component Analysis (PCA), and Analysis of Variant (ANOVA) used in the identification the most significant pollutant sources in each area. By knowing the main pollutant in the area, more emphasis can be given to improve the situation towards better water quality. The concept of the watershed is very broad and could be used to denote the river basin and its management. Here in this review emphasis is laid on the derivative of the watershed, in other word river basin system and the attendant pollution (Sultan et al. 2011). Researchers like Cohen and Davison (2011) and Qin et al. (2018) suggested that watershed governance unit be separated from its technical tools this way it will address the attendant challenges associated with it. The emphasis of this review is the attendant derivative of watershed governance or the lack of it.

Sungai Langat is a major river in Selangor State, where water quality research determination has been carried out by researchers. Azrina et al. (2006) documented the use of bioindicators of pollution to study the brunt of human actions on the quality of water as well as species diversity and dissemination of the macrobenthic invertebrates of Sungai Langat. The results showed that the upstream stations of Sungai Langat, with better water quality, had a higher species diversity than the downstream stations, which are close contact to densely populated areas. In 2011, Juahir et al. reported the spatial variation of water quality of Sungai Langat Basin using environmetric methods (i.e. the hierarchical agglomerative cluster analysis (HACA), the discriminant analysis (DA), the principal component analysis (PCA), and the factor analysis (FA)), founded on the water quality data taken between the year 1995-2002. It was suggested that the sources of pollution included industrial discharge, wastewater treatment plant, domestic as well as marketable waste, agricultural runoffs, as well as forest areas. The study also prompted the revision of the parameters applied to the Water Quality Index (WQI) calculation as the present WQI was not comprehensive in providing an overall picture of the quality of water for a river basin. The previous study had also mentioned on the investigation of the spatial variability of element content of selected metals found in river waters as well as sediments associated to Sungai Langat (Wan Maznah \& Mansor 2002). The study showed that arsenic (As) concentrations, lead $(\mathrm{Pb})$ as well as chromium $(\mathrm{Cr})$ found in selected sediment samples exceeded the Canadian Interim Sediment Quality Guidelines (ISQG). The elevated concentrations of these metals in the surface sediments of Sungai Langat might constitute a threat to the aquatic ecosystem and in turn, to the usability of the water resources for various purposes. The study also noted that the increase of the metal load in the river might be as a result of anthropogenic sources, like industrial and domestic wastes. Besides, the results of the studies conducted during the different seasons; all show how Sungai Langat water quality is poor.

Meanwhile, Sultan and Shazili (2009) discovered the presence of contaminants (rare earth elements) in the surface water of Sungai Terengganu Basin and soil sediments of the same river basin; from their study, they observed that dissolved rare earth element concentration increased systematically in surface waters. Total dissolved solids were said to be the major controlling factors (Table 1). They also viewed that the pollutions from natural resources are one of the major challenges associated with industrial development and urbanisation along the north coast of Peninsular Malaysia. 
TABLE 1. Statistical data of analytical results of soil, sediment and surface water of Sungai Terengganu basin $(\mu \mathrm{g} / \mathrm{kg})(\mathrm{Sultan} \&$ Shazili 2009)

\begin{tabular}{|c|c|c|c|c|c|c|c|}
\hline Media & Elements & Minimum & Average & Maximum & $\begin{array}{l}\text { Standard } \\
\text { Deviation }\end{array}$ & Median & Count \\
\hline \multirow[t]{14}{*}{ Soil } & $\mathrm{La}$ & 1698.2 & 24236.5 & 49744.8 & 11165.0 & 23380.9 & 52 \\
\hline & $\mathrm{Ce}$ & 2901.1 & 61807.2 & 158154.5 & 33454.9 & 55588.8 & 52 \\
\hline & $\operatorname{Pr}$ & 148.3 & 3826.9 & 8328.3 & 1774.6 & 3483.1 & 52 \\
\hline & $\mathrm{Nd}$ & 441.8 & 11711.0 & 28031.3 & 5386.1 & 10844.5 & 52 \\
\hline & $\mathrm{Sm}$ & 70.9 & 1770.7 & 4288.3 & 757.2 & 1691.6 & 52 \\
\hline & $\mathrm{Eu}$ & 17.3 & 338.3 & 814.2 & 139.7 & 332.8 & 52 \\
\hline & $\mathrm{Gd}$ & 109.6 & 2414.9 & 5665.7 & 1154.3 & 2152.0 & 52 \\
\hline & $\mathrm{Tb}$ & 16.0 & 362.5 & 812.8 & 164.6 & 336.8 & 52 \\
\hline & Dy & 74.1 & 1310.8 & 2877.0 & 611.1 & 1269.3 & 52 \\
\hline & Но & 19.1 & 253.9 & 587.1 & 129.5 & 221.2 & 52 \\
\hline & $\mathrm{Er}$ & 70.9 & 876.9 & 1995.3 & 420.8 & 798.3 & 52 \\
\hline & $\mathrm{Tm}$ & 12.0 & 113.2 & 311.2 & 59.2 & 106.4 & 52 \\
\hline & $\mathrm{Yb}$ & 77.4 & 722.6 & 2046.9 & 367.6 & 680.4 & 52 \\
\hline & $\mathrm{Lu}$ & 10.5 & 134.5 & 418.8 & 72.5 & 126.3 & 52 \\
\hline \multirow[t]{14}{*}{ Sediment } & $\mathrm{La}$ & 207.4 & 29600.0 & 76901.5 & 17228.8 & 29569.2 & 42 \\
\hline & $\mathrm{Ce}$ & 758.8 & 66990.7 & 184123.4 & 42945.8 & 64540.2 & 42 \\
\hline & $\operatorname{Pr}$ & 54.3 & 4578.0 & 12350.8 & 2767.0 & 4603.5 & 42 \\
\hline & $\mathrm{Nd}$ & 198.6 & 14512.3 & 39529.1 & 8967.7 & 14044.1 & 42 \\
\hline & $\mathrm{Sm}$ & 244.3 & 2269.1 & 5751.3 & 1272.9 & 2100.2 & 42 \\
\hline & $\mathrm{Eu}$ & 49.8 & 428.9 & 937.3 & 191.8 & 414.4 & 42 \\
\hline & $\mathrm{Gd}$ & 35.3 & 3367.7 & 8480.0 & 2047.0 & 3041.7 & 42 \\
\hline & $\mathrm{Tb}$ & 13.3 & 479.2 & 1022.6 & 254.4 & 454.7 & 42 \\
\hline & Dy & 73.9 & 1838.0 & 4258.1 & 947.9 & 1818.6 & 42 \\
\hline & Ho & 19.2 & 375.5 & 913.3 & 197.4 & 360.3 & 42 \\
\hline & Er & 63.1 & 1257.1 & 2921.8 & 642.9 & 1211.9 & 42 \\
\hline & $\mathrm{Tm}$ & 10.6 & 170.7 & 406.0 & 88.1 & 166.9 & 42 \\
\hline & $\mathrm{Yb}$ & 65.6 & 1074.3 & 2488.7 & 543.2 & 1069.2 & 42 \\
\hline & $\mathrm{Lu}$ & 14.2 & 210.1 & 485.0 & 105.9 & 210.1 & 42 \\
\hline \multirow[t]{14}{*}{ Surface water } & $\mathrm{La}$ & 0.0291 & 1.94 & 12.85 & 2.83 & 0.62 & 51 \\
\hline & $\mathrm{Ce}$ & 0.0216 & 3.74 & 24.36 & 6.01 & 0.94 & 51 \\
\hline & $\operatorname{Pr}$ & 0.0019 & 0.39 & 2.85 & 0.60 & 0.12 & 51 \\
\hline & $\mathrm{Nd}$ & 0.0071 & 1.26 & 6.68 & 1.82 & 0.42 & 51 \\
\hline & $\mathrm{Sm}$ & 0.0022 & 0.23 & 1.62 & 0.32 & 0.12 & 51 \\
\hline & $\mathrm{Eu}$ & 0.0008 & 0.05 & 0.29 & 0.06 & 0.03 & 51 \\
\hline & Gd & 0.0026 & 0.36 & 2.44 & 0.61 & 0.09 & 51 \\
\hline & $\mathrm{Tb}$ & 0.0005 & 0.08 & 0.51 & 0.11 & 0.04 & 51 \\
\hline & Dy & 0.0038 & 0.34 & 1.93 & 0.47 & 0.14 & 51 \\
\hline & Ho & 0.0018 & 0.09 & 0.52 & 0.11 & 0.06 & 51 \\
\hline & Er & 0.0080 & 0.21 & 1.29 & 0.28 & 0.11 & 51 \\
\hline & $\mathrm{Tm}$ & 0.0015 & 0.04 & 0.15 & 0.03 & 0.03 & 51 \\
\hline & $\mathrm{Yb}$ & 0.0103 & 0.14 & 0.91 & 0.17 & 0.08 & 51 \\
\hline & $\mathrm{Lu}$ & 0.0013 & 0.02 & 0.09 & 0.02 & 0.01 & 51 \\
\hline
\end{tabular}


Another study (Park et al. 2011) compared the variation of surface water quality among 11 watersheds in eight countries including Malaysia; they found that the concentration of dissolved ions tends to be higher during the dry period while the concentration of suspended sediments and dissolved organic matter are significantly higher during the wet period. It is certainly shown from their report that rapid urbanisation and agricultural expansion increased water pollution in their studied area (Kota Kinabalu) (Figure 3).

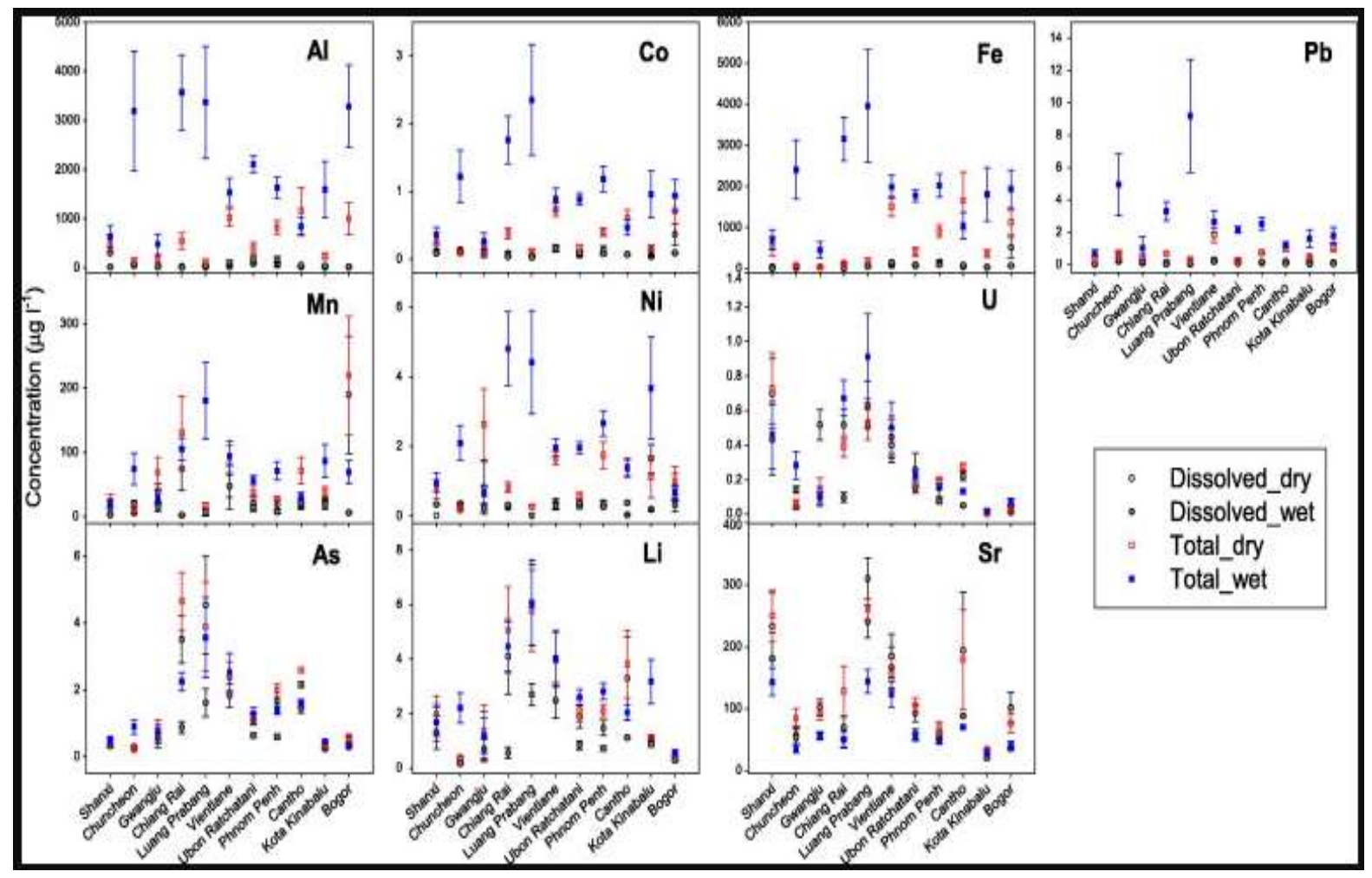

FIGURE 3. Seasonal differences in mean concentrations of dissolved and total metals between dry and wet periods at 11 watersheds monitored during 2006 and 2007/2008 (Park et al. 2011)

According to Narany et al. (2017), the activities associated with land use have an essential brunt on the aquifer system that is shallow. The flaccid aquifers are of great concern with regards to groundwater contamination, notably at the point the super-imposed layer is comparatively lean and permeable. According to published works, it is predicted that there will be a massive increase in land-use activities concerning crops, rubber plantation, palm oil, and paddy thereby resulting to a significant increase in the concentration nitrate in shallow aquifers. The increase in population, destruction of natural grassland and forests for urban development and massive agricultural activities is a source of potential contaminant such as fertilisers, landfills, sewages; this often influenced changes in the hydrological system as well as runoff and quality of water (Chen et al. 2010; Garcia-Diaz 2011; Kurunc et al. 2016; Nur Hayati 2011; Razali et al. 2018; Zhang et al. 2013).

The study further predicted contamination from nitrate between 2015 and 2030 of agricultural and 
residential wells (Figure 4). The challenges facing water quality in Malaysia requires a concerted effort from the government as well as the public. Achieving good water quality is increasingly becoming difficult. It has been empirically and theoretically, that water quality improvement as a result of the investment will produce enormous economic benefit ranging from, environmental to social benefits. The quality of water for humans, ecology, as well as economic developments, are of great importance as seen in several indices of water quality. The quality of water is dependent on the origin, area, and the planned purpose of use of the water. Moreover, water quality index has several important limitations, for example, constantly, insufficient as well as commensurate data audit on a wide spectrum of parameters used to characterised water quality (Kurunc et al. 2011; Lawniczak et al. 2016; Manassaram et. 2007; Powlson et al. 2008; Sheikhy Narany et al. 2013).
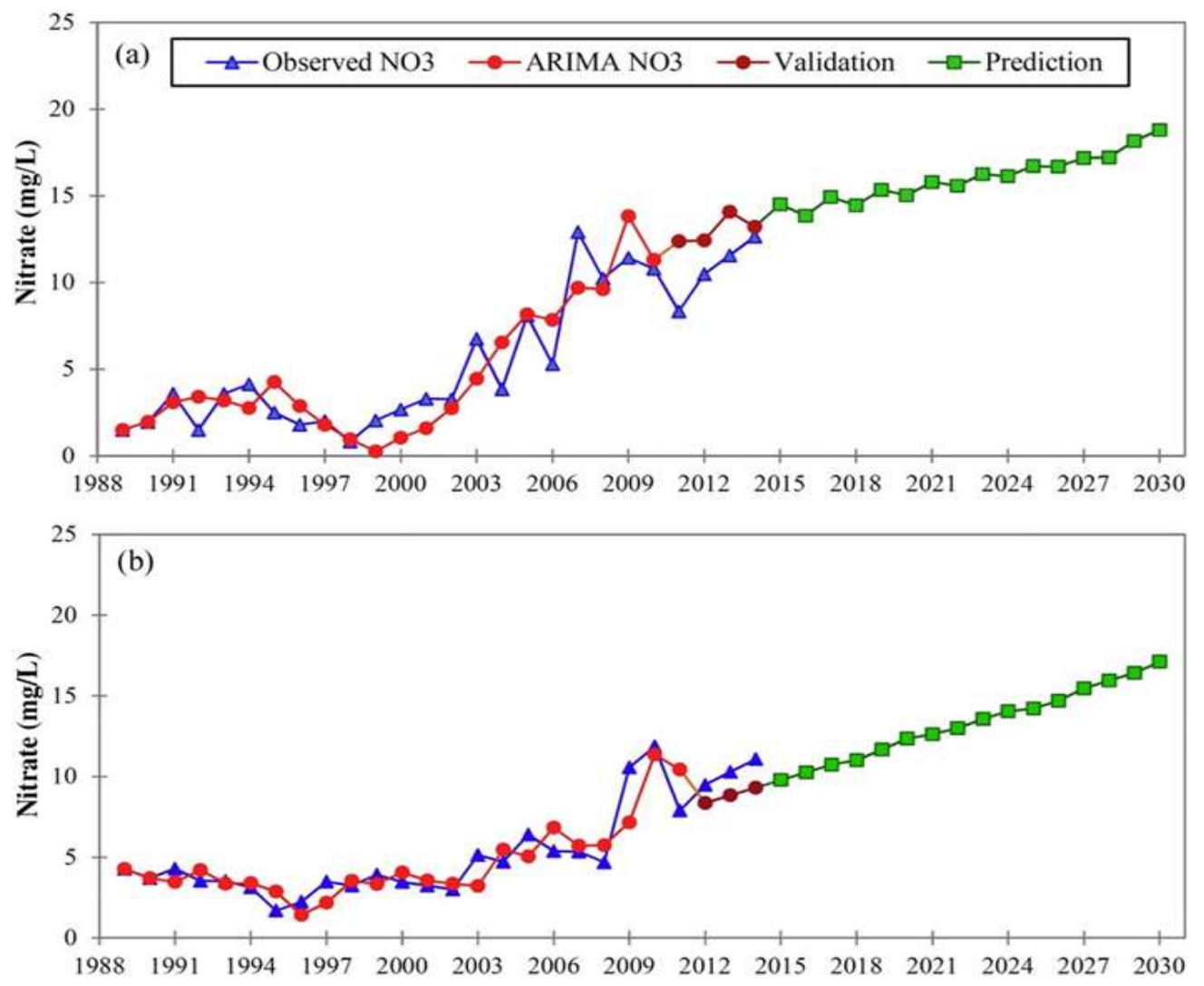

FIGURE 4. Prediction of nitrate contamination from 2015 to 2030 in agricultural well (a) and residential wells, and (b) in Northern Kelantan (Narany et al. 2017)

Srebotnjak et al. (2012) also noted the importance of the quality of water for a wide spectrum of various anthropogenic use which falls under the capacity and scope of environmental management scheme, both at the national level as well as globally. Thus, it is of great importance to evaluate as well as compare Malaysia's performance in improving the quality of water, and the protection for humans as well as water usage ecologically. 


\section{MICROBIAL CONTAMINATION STUDIES}

While most studies focused on the simple and rapid indicators such as parameters (i.e. E. coli) (Jung et al. 2014), waterborne diseases caused by microorganisms are rarely investigated (Poma et al. 2012). The microbial contamination of water bodies has been a constant subject of interest and is often faecal related to humans (e.g. water sewage treatment plants), domesticated animals (manure spreading), or wildlife (Jung et al. 2014). As of to date, numerous studies on microorganisms had been conducted from various water sources ranging from bacteriological (AlOtaibi 2009) followed by parasitological (Azlan et al. 2016; Richard et al. 2016) to fungal (Babic et al. 2017; Mesquita-Rocha et al. 2013) and virological studies (Borchardt et al. 2012).

The waterborne diseases due to parasites have been one of the leading source of outbreaks worldwide (Baldursson \& Karanis 2011; Efstratiou et al. 2017; Karanis et al. 2007) and are widely distributed in numerous environments (Greub \& Raoult 2004). Cryptosporidium parvum, Giardia lamblia, Blastocystis sp., Acanthamoeba spp., N. fowleri and $V$. vermiformis are considered pathogenic to humans and able to cause cryptosporidiosis, giardiasis, blastocystosis, granulomatous amoebic encephalitis (GAE), primary amoebic meningoencephalitis (PAM), and keratitis, respectively (Benedict et al. 2019; Cekin et al. 2012; Rocha-Azevedo et al. 2009). In Malaysia, several studies with regards to parasites contaminations had been carried out over the years. Cryptosporidium and Giardia had been isolated from various water bodies in zoos, recreational lakes, drinking water treatment plants, and rivers (Azlan et al. 2016; Kumar et al. 2014; Lee et al. 2014; Lim et al. 2009; Richard et al. 2016) followed by Blastocystis had been detected from rivers, and sewage systems (Noradilah et al. 2016; Suresh et al. 2005) while free-living amoeba had been detected in swimming pools, recreational lakes, and drinking water treatment plants (Azlan et al. 2016; Gabriel et al. 2018; Kumar et al. 2014; Richard et al. 2016). Moreover, helminths have also been found from drinking water treatment plants and recreational pools (Kumar et al. 2014; Richard et al. 2016). Despite the ongoing studies on waterborne parasites, the research area still has not received much attention yet due to the lack of experts and limited detection techniques. Therefore, it is pivotal to understand the water quality and its impact towards the public health as $10 \%$ of the world's total disease burden is mostly attributed to unsafe water and lack of appropriate sanitation, that resulted in millions of preventable deaths each year (Meinhardt 2017).

\section{KEY CHALLENGES IN MALAYSIAN WATER \\ MANAGEMENT}

Mamun and Zainudin (2013) highlighted the diversified water laws in Malaysia, which are focused on limited aspects of water resources and difficult to be enforced effectively. Thus, they suggested a comprehensive water law to be enacted to overcome water quantity and quality issues. Currently, Malaysia applied several policies of water resources (Rafia \& Ataur 2017). The National Environmental Policy highlighted strategies and actions towards effective management of water resources and overcoming pollution and environmental degradation. Several acts have been developed to control river water pollution; the earliest was Water Act 1920 that was initiated in the 1920s. Later in 1974, the Environmental Quality Act (EQA) was created to overcome the limitation of Water Act 1920. Other most important acts that indirectly related to the prevention of water pollution were Street, Drainage and Building Act in 1974 and the Town and Country Planning Act 1976. Other legislation to control water pollution were included in the Mining Act 1929, the Forest Enactment 1935, the Drainage Work Ordinance 1954 and the Land Conservation Act 1960 (Mamun \& Zainudin 2013).

The country's water services are still shared between Federal and State Governments in Malaysia. Both bodies are attaining different roles in dealing with water-related matters with federal agencies being responsible for the planning, research and development of water resources while state bodies focus on the infrastructure development of water supply that includes financing, operation, and maintenance. Besides, each state has different guidelines on its water processes and management. Moreover, the federal government has also distributed the water resources and supply management to several departments under different ministries namely the Department of Irrigation and Drainage (DID), the Public Works Department (PWD), Department of Environment (DOE), the Ministry of Health $(\mathrm{MOH})$ and the Ministry of Energy, Green Technology and Water. Each of these departments varies in their respective tasks. Hence, many guidelines and reports need to comply (Saimy \& Mohamed Yusof 2013). Thus, the increasing amount of unclear information may cause a huge impact on the water supply resulting in water shortages as well as elucidating the problems of water quality in the future as well as enraged conflict of interests between the federal and state government, similar to the ones that occurred between Selangor and 'Syarikat Bekalan Air Selangor' or SYABAS (Saimy \& Mohamed Yusof 2013). Given these situations, similar cases can occur in other states. 
Meanwhile, in Sabah and Sarawak, deforestation and logging activities are considered two major elements that had led to the devastating effect of the contamination of water that had since affected the communities as well as wildlife. As a result, obtaining potable water for consumption and daily use is in high demand but yet costly for the locals. To date, both states are still in control of their water supplies management and services (Saimy \& Mohamed Yusof 2013). The various regulatory challenges are not the only challenges facing water management in the country. The implementation of protective-policies on water also posses a challenge (Muyibi et al. 2008b) as point and non-point sources of pollutant tend to affect water catchments in Malaysia. Climate change is another big challenge in water management in the country (Amin et al. 2017) as it affects the dry and wet spell in the country with flooding and extreme weather conditions. Lack of awareness among people is also a big challenge that needs to be addressed. Point and non-point source polluters need to know how their activities could constitute sources of contaminant to water quality.

\section{CONCLUSION}

As shown by the works of previous authors reviewed in this report; destruction of the forest, as well as agricultural expansions, are presumed to impact the quality of groundwater significantly. With almost 27 years of available data for quality of groundwater showed a negative effect of human anthropogenic actions with an increase in nutrients input to the environment as a consequence of spilt sewage, as well as chemical fertilisers. The shallow aquifers showed vulnerability to nitrate contamination than the deeper aquifers. Deteriorating quality of groundwater is a phenomenal problem with the non-existence of any land as well as water management. All reviewed articles only identified the problems with contamination of surface and groundwater in Malaysia, but no conscious effort is made to resolve the issues. Various possible solutions that can be employed and attempted by the authorities and the public in curbing the endless water-related matter. Firstly, the increased proper monitoring and enforcement are essential to understand the water bodies and their surroundings that may influence the quality as well as provide beneficial information, especially on contamination events that can be useful for future studies. Researchers and scientists, having enhanced knowledge from various related fields, will also be able to work hand-in-hand with other key stakeholders to investigate the possible cause and postulate current methods to deal with the issues. Besides, public awareness is also important to educate the public on the importance of maintaining and preserving our water resources to avoid any possible water-related diseases that can affect humans as well as the ecosystem. Finally, water policies in Malaysia are vital to improving the treatment processes as well as the overall management of our water systems. These policies should be regularly reviewed and revised to ensure consistent works and guidelines are being adhered.

\section{REFERENCES}

Abdullah, A.M. \& Zainudin, Z. 2013. Sustainable river water quality management in Malaysia. IIUM Engineering Journal 14(1): 29-42.

Afroz, R. \& Rahman, A. 2017. Health impact of river water pollution in Malaysia. International Journal of Advanced and Applied Sciences 4(5): 78-85.

Afroz, R., Masud, M.M., Akhtar, R. \& Duasa, J.B. 2014. Water pollution: Challenges and future direction for water resource management policies in Malaysia. Environment and Urbanization ASIA 5(1): 63-81.

Ahmed, A.N., Othman, F.B., Afan, H.A., Ibrahim, R.K., Fai, C.M., Hossain, M.S., Ehteram, M. \& Elshafie, A. 2019. Machine learning methods for better water quality prediction. Journal of Hydrology 578: 124084.

Al-Odaini, N.A., Zakaria, M.P., Yaziz, M.I., Surif, S. \& Kannan, N. 2013. The occurrence of synthetic hormones in sewage effluents and Langat River and its tributaries, Malaysia. International Journal of Environmental Analytical Chemistry 93(14): 1457-1469.

Al Otaibi, E.L.S. 2009. Bacteriological assessment of urban water sources in Khamis Mushait Governorate, southwestern Saudi Arabia. International Journal of Health Geographics 8: 16.

Amin, M.Z.M., Shaaban, A.J., Ercan, A., Ishida, K., Kavvas, M.L., Chen, Z.Q. \& Jang, S. 2017. Future climate change impact assessment of watershed-scale hydrologic processes in Peninsular Malaysia by a regional climate model coupled with physically-based hydrology models. Science of The Total Environment 575: 12-22.

Aris, A.H. \& Mohd Isa, N. 2012. Preliminary assessment on the hydro-geochemistry of Kapas Island Terengganu. Sains Malaysiana 41(1): 23-32.

Azlan, A.M., Rasid, M.N., Richard, R.L., Mahboob, T., Sritongchuen, C., Jaturas, N., Tan, T.C., Sawangjaroen, N., Lim, Y.A.L. \& Nissapatorn, V. 2016. Titiwangsa lake a source of an urban parasitic contamination. Tropical Biomedicine 33(3): 1-5.

Azrina, M.Z., Yap, C.K., Rahim Ismail, A., Ismail, A. \& Tan, S.G. 2006. Anthropogenic impacts on the distribution and biodiversity of benthic macroinvertebrates and water quality of the Langat River, Peninsular Malaysia. Ecotoxicology and Environmental Safety 64(3): 337-347.

Babič, M.N., Gunde-Cimerman, N., Vargha, M., Tischner, Z., Magyar, D., Veríssimo, C., Sabino, R., Viegas, C., Meyer, W. 
\& Brandão, J. 2017. Fungal contaminants in drinking water regulation? A tale of ecology, exposure, purification and clinical relevance. International Journal of Environmental Research and Public Health 14(6): 636.

Baharuddin, M.F.T., Taib, S., Hashim, R., Abidin, M.H.Z. \& Rahman, N.I. 2013. Assessment of seawater intrusion to the agricultural sustainability at the coastal area of Carey Island, Selangor, Malaysia. Arabian Journal of Geosciences 6(10): 3909- 3928.

Baldursson, S. \& Karanis, P. 2011. Waterborne transmission of protozoan parasites: A review of worldwide outbreaks and update 2004-2010. Water Research 45(20): 6603-6014.

Benedict, K.M., Collier, S.A., Marder, E.P., Hlavsa, M.C., Fullerton, K.E. \& Yoder, J.S. 2019. Case-case analyses of cryptosporidiosis and giardiasis using routine national surveillance data in the United States - 2005-2015. Epidemiology and Infection 147: e178.

Borchardt, M.A., Spencer, S.K., Kieke, B.A., Lambertini, E. \& Loge, F.J. 2012. Viruses in nondisinfected drinking water from municipal wells and community incidence of acute gastrointestinal illness. Environmental Health Perspectives 120(9): 1272-1279.

Camara, M., Jamil, N.R. \& Abdullah, A.F.B. 2019. Impact of land uses on water quality in Malaysia: A review. Ecological Processes 8(1): 10.

Cekin, A.H., Cekin, Y., Adakan, Y., Tasdemir, E., Koclar, F.G. \& Yolcular, B.O. 2012. Blastocystis in patients with gastrointestinal symptoms: A case-control study. $B M C$ Gastroenterology 12: 122

Chan, N.W. 2012. Managing urban rivers and water quality in Malaysia for sustainable water resources. International Journal of Water Resources Development 28(2): 343-354.

Chappell, N.A., Jones, T.D. \& Tych, W. 2017. Sampling frequency for water quality variables in streams: Systems analysis to quantify minimum monitoring rates. Water Research 123: 49-57.

Chen, S., Wu, W., Hu, K. \& Li, W. 2010. The effects of land-use change and irrigation water resource on nitrate contamination in shallow groundwater at the county scale. Ecological Complexity 7(2): 131-138.

Chong, F.S. \& Tan, D.N. 1986. Hydrogeological activities in Peninsular Malaysia and Sarawak. Volume ii. GEOSEA $V$ Proceeding. pp. 827-842.

Cohen, A. \& Davidson, S. 2011. The watershed approach: Challenges, antecedents, and the transition from technical tool to governance unit. Water Alternatives 4(1): 1 .

Deni, S.M., Suhaila, J., Zin, W.Z.W. \& Jemain, A.A. 2010. Spatial trends of dry spells over Peninsular Malaysia during monsoon seasons. Theoretical and Applied Climatology 99(3-4): 357.

Efstratiou, A., Ongerth, J.E. \& Karanis, P. 2017. Waterborne transmission of protozoan parasites: Review of worldwide outbreaks - An update 2011-2016. Water Research 114: 14-22.

Evans, A.E., Hanjra, M.A., Jiang, Y., Qadir, M. \& Drechsel, P. 2012. Water quality: Assessment of the current situation in Asia. International Journal of Water Resources Development 28(2): 195-216.

Fulazzaky, M.A., Seong, T.W. \& Masirin, M.I.M. 2010 Assessment of water quality status for the Selangor River in Malaysia. Water, Air, and Soil Pollution 205(1-4): 63.

Gabriel, S., Khan, N.A. \& Siddiqui, R. 2019. The occurrence of free-living amoebae (Acanthamoeba, Balamuthia, Naegleria) in water samples in Peninsular Malaysia. Journal of Water Health 17(1): 160-171.

García-Díaz, J.C. 2011. Monitoring and forecasting nitrate concentration in the groundwater using statistical process control and time series analysis: A case study. Stochastic Environmental Research and Risk Assessment 25(3): 331339.

Gazzaz, N.M., Yusoff, M.K., Ramli, M.F., Aris, A.Z. \& Juahir, H. 2012a. Characterization of spatial patterns in river water quality using chemometric pattern recognition techniques. Marine Pollution Bulletin 64(4): 688-698.

Gazzaz, N.M., Yusoff, M.K., Aris, A.Z., Juahir, H. \& Ramli, M.F. 2012b. Artificial neural network modelling of the water quality index for Kinta River (Malaysia) using water quality variables as predictors. Marine Pollution Bulletin 64(11): 2409-2420

Greub, G. \& Raoult, D. 2004. Microorganisms resistant to freeliving amoebae. Clin. Microbiol. Rev. 17: 413-433.

Hua, A.K. 2017. Land use land cover changes in detection of water quality: A study based on remote sensing and multivariate statistics. Journal of Environmental and Public Health 2017: Article ID. 7515130.

Hafizi Lani, N., Yusop, Z. \& Syafiuddin, A. 2018. A review of rainwater harvesting in Malaysia: Prospects and challenges. Water 10(4): 506.

Hezri, A.A. \& Nordin Hasan, M. 2006. Towards sustainable development? The evolution of environmental policy in Malaysia. In Natural Resources Forum. Oxford: Blackwell Publications. pp. 37-50.

Huang, Y.F., Ang, S.Y., Lee, K.M. \& Lee, T.S. 2015. Quality of water resources in Malaysia. In Research and Practices in Water Quality. https://www.intechopen.com/books/ research-and-practices-in-water-quality/quality-of-waterresources-in-malaysia.

Ismail, Z., Salim, K., Othman, S.Z., Ramli, A.H., Shirazi, S.M., Karim, R. \& Khoo, S.Y. 2013. Determining and comparing the levels of heavy metal concentrations in two selected urban river water. Measurement 46(10): 4135-4144

Isobe, K.O., Tarao, M., Zakaria, M.P., Chiem, N.H., Minh, L.Y \& Takada, H. 2002. Quantitative application of faecal sterols using gas chromatography-mass spectrometry to investigate faecal pollution in tropical waters: Western Malaysia and Mekong Delta, Vietnam. Environmental Science \& Technology 36(21): 4497-4507.

Juahir, H., Zain, S.M., Yusoff, M.K., Hanidza, T.I.T., Armi, A.S.M., Toriman, M.E. \& Mokhtar, M. 2011. Spatial water quality assessment of Langat River Basin (Malaysia) using 
environmetric techniques. Environmental Monitoring and Assessment 173(1): 625-641.

Jung, A.V., Le Cann, P., Roig, B., Thomas, O., Baurès, E. \& Thomas, M.F. 2014. Microbial contamination detection in water resources: Interest of current optical methods, trends and needs in the context of climate change. International Journal of Environmental Research and Public Health 11(4): 4292-4310.

Kabiri, R., Bai, V.R. \& Chan, A. 2015. Assessment of hydrologic impacts of climate change on the runoff trend in Klang Watershed, Malaysia. Environmental Earth Sciences 73(1): 27-37.

Karanis, P., Kourenti, C. \& Smith, H. 2007. Waterborne transmission of protozoan parasites: A worldwide review of outbreaks and lessons learnt. Journal of Water Health 5(1): 1-38.

Keshavarzifard, M., Zakaria, M.P., Hwai, T.S., Mustafa, S., Vaezzadeh, V., Magam, S.M., Masood, N., Alkhadher, S.A. \& Abootalebi-Jahromi, F. 2014. Baseline distributions and sources of Polycyclic Aromatic Hydrocarbons (PAHs) in the surface sediments from the Prai and Malacca Rivers, Peninsular Malaysia. Marine Pollution Bulletin 88(1): 366372

Koki, I.B., Low, K.H., Juahir, H., Zali, M.A., Azid, A. \& Zain, S.M. 2018. Consumption of water from ex-mining ponds in Klang Valley and Melaka, Malaysia: A health risk study. Chemosphere 195: 641-652.

Kumar, T., Onichandran, S., Lim, Y.A., Sawangjaroen, N., Ithoi, I., Andiappan, H., Salibay, C.C., Dungca, J.Z., Chye, T.T., Sulaiman, W.Y. \& Lau, Y.L. 2014. Comparative study on waterborne parasites between Malaysia and Thailand: A new insight. American Journal of Tropical Medicine and Hygiene 90(4): 682-689.

Kurunc, A., Ersahin, S., Sonmez, N.K., Kaman, H., Uz, I., Uz, B.Y. \& Aslan, G.E. 2016. Seasonal changes of spatial variation of some groundwater quality variables in a large irrigated coastal Mediterranean region of Turkey. Science of The Total Environement 554: 53-63.

Kurunc, A., Ersahin, S., Uz, B.Y., Sonmez, N.K., Uz, I., Kaman, H. \& Emekli, Y. 2011. Identification of nitrate leaching hot spots in a large area with contrasting soil texture and management. Agricultural Water Management 98(6): 10131019.

Lawniczak, A.E., Zbierska, J., Nowak, B., Achtenberg, K., Grześkowiak, A. \& Kanas, K. 2016. Impact of agriculture and land use on nitrate contamination in groundwater and running waters in central-west Poland. Environmental Monitoring Assessment 188(3): 1-17.

Lee, S.C., Ngui, R., Tan, T.K., Roslan, M.A., Ithoi, I. \& Lim, Y.A.L. 2014. Aquatic biomonitoring of Giardia cysts and Cryptosporidium oocysts in Peninsular Malaysia. Environmental Science and Pollution Research 21: 445453.

Leong, K.H., Tan, B.L.L. \& Mustafa, A.M. 2007. Contamination levels of selected organochlorine and organophosphate pesticides in the Selangor River, Malaysia between 2002 and 2003. Chemosphere 66(6): 1153-1159.

Ling, T.Y., Soo, C.L., Sivalingam, J.R., Nyanti, L., Sim, S.F. \& Grinding, J. 2016. Assessment of the water and sediment quality of tropical forest streams in upper reaches of the Baleh River, Sarawak, Malaysia, subjected to logging activities. Journal of Chemistry 2016: Article ID. 8503931.

Lim, Y.A.L., Lai, M.M., Mahdy, M.A.K., Mat Naim, H.R. \& Smith, H.V. 2009. Molecular detection of Giardia contamination in water bodies in a zoo. Environmental Research 109: 857-859.

Mamun, A.A. \& Zainudin, Z. 2013. Sustainable river water quality management in Malaysia. IIUM Engineering Journal 14(1): 29-42.

Manassaram, D.M., Backer, L.C. \& Moll, D.M. 2007. A review of nitrates in drinking water: Maternal exposure and adverse reproductive and developmental outcomes. Environmental Health Perspective 12(1): 153-163.

Mayowa, O.O., Pour, S.H., Shahid, S., Mohsenipour, M., Harun, S.B., Heryansyah, A. \& Ismail, T. 2015. Trends in rainfall and rainfall-related extremes in the east coast of peninsular Malaysia. Journal of Earth System Science 124(8): 16091622.

Meinhardt, P.L. 2017. Water Quality and Water-Related Disease. https:/www.oxfordbibliographies.com/view/document/obo9780199756797/obo-9780199756797-0052.xml.

Mesquita-Rocha, S., Godoy-Martinez, P.C., Gonçalves, S.S., Urrutia, M.D., Carlesse, F., Seber, A., Silva, M.A.A., Petrilli, A.S. \& Colombo, A.L. 2013. The water supply system as a potential source of fungal infection in paediatric haematopoietic stem cell units. BMC Infectious Diseases 13: 289.

Mohd. Saiful, S., Azman, A., Saiful Iskandar, K., Ahmad Shakir, M.S. \& Muhammad Amar, Z. 2017. River water quality assessment using APCS-MLR and statistical process control in Johor River Basin, Malaysia. International Journal of Advanced and Applied Sciences 48: 84-97.

Mohamad, J., Mustafa, F.B. \& Wan-Sobri, W.M.A. 2010. Water governance in Peninsular Malaysia: Strategies for reform. The $6^{\text {th }}$ Annual International Sustainable Development Research Conference. pp. 1-10.

Muyibi, S.A., Ambali, A.R. \& Eissa, G.S. 2008a. Developmentinduced water pollution in Malaysia: Policy implications from econometric analysis. Water Policy 10(2): 193- 206.

Muyibi, S.A., Ambali, A.R. \& Eissa, G.S. 2008b. The impact of economic development on water pollution: Trends and policy actions in Malaysia. Water Resources Management 22(4): 485-508.

Narany, T.S., Aris, A.Z., Sefie, A. \& Keesstra, S. 2017. Detecting and predicting the impact of land-use changes on groundwater quality, a case study in Northern Kelantan, Malaysia. Science of The Total Environment 599: 844853.

Naubi, I., Zardari, N.H., Shirazi, S.M., Ibrahim, N.F.B. \& Baloo, L. 2016. Effectiveness of water quality index for 
monitoring Malaysian river water quality. Polish Journal of Environmental Studies 25(1): 231-239.

Noradilah, S.A., Lee, I.L., Anuar, T.S., Salleh, F.M., Manap, S.N.A.A., Mohtar, N.S.H.M., Azrul, S.M., Abdullah, W.O. \& Moktar, N. 2016. The occurrence of Blastocystis sp. in water catchments at Malay villages and Aboriginal settlement during wet and dry seasons in Peninsular Malaysia. PeerJ 4: e2541.

Nur-Hayati, H. 2011. Hydrogeochemical study and iron removal of groundwater in North Kelantan. University of Malaya. Ph.D. Thesis (Unpublished).

Omar, T.F.T., Aris, A.Z., Yusoff, F.M. \& Mustafa, S. 2018. Occurrence, distribution, and sources of emerging organic contaminants in tropical coastal sediments of anthropogenically impacted Klang River estuary, Malaysia. Marine Pollution Bulletin 131: 284-293.

Palani, S., Liong, S.Y. \& Tkalich, P. 2008. An ANN application for water quality forecasting. Mar. Pollut. Bull. 56: 15861597.

Park, J.H., Inam, E., Abdullah, M.H., Agustiyani, D., Duan, L., Hoang, T.T., Kim, K.W., Kim, S.D., Nguyen, M.H., Pekthong, T. \& Sao, V. 2011. Implications of rainfall variability for seasonality and climate-induced risks concerning surface water quality in East Asia. Journal of Hydrology 400(3-4): 323-332.

Poma, H.R., Gutierrez Cacciabue, D., Garce, B., Gonzo, E.E. \& Rajal, V.B. 2012. Towards a rational strategy for monitoring of the microbiological quality of ambient waters. Science of The Total Environment 433: 98-109.

Powlson, D.S., Addiscott, T.M., Benjamin, N., Cassman, K.G., de Kok, T.M., van Grinsven, H., L'hirondel, J.L., Avery, A.A. \& Van Kessel, C. 2008. When does nitrate become a risk for humans? Journal of Environmental Quality 37(2): 291-295.

Pujari, P.R. \& Soni, A.K. 2008. Seawater intrusion studies near Kovaya limestone mine, Saurashtra coast, India. Environmental Monitoring and Assessment 154(1-4): 93109

Qin, C.Z., Gao, H.R., Zhu, L.J., Zhu, A.X., Liu, J.Z. \& Wu, H. 2018. Spatial optimization of watershed best management practices based on slope position units. Journal of Soil and Water Conservation 73(5): 504-517.

Rafia, A. \& Ataur, R. 2017. Health impact of river water pollution in Malaysia. International Journal of Advanced and Applied Sciences 4(5): 78-85.

Rak, A.E., Said, I., Mohamed, M. \& Abas, A. 2011. Effect of logging activities on water quality and benthic macroinvertebrate assemblages of Madek River Basin, Kluang, Johor, Malaysia. Journal of Applied Sciences and Environmental Management 15(2): 337-340.

Razali, A., Ismail, S.N.S., Awang, S., Praveena, S.M. \& Abidin, E.Z. 2018. Land-use change in the highland area and its impact on river water quality: A review of case studies in Malaysia. Ecological Processes 7: 19.
Richard, R.L., Ithoi, I., Abd Majid, M.A., Wan Sulaiman, W.Y., Tan, T.C., Nissapatorn, V. \& Lim, Y.A.L. 2016. Monitoring of waterborne parasites in two drinking water treatment plants: A study in Sarawak, Malaysia. International Journal of Environmental Research and Public Health 13(7): 641.

Rocha-Azevedo, B.D., Jamerson, M., Cabral, G.A., SilvaFilho, F.C. \& Marciano-Cabral, F. 2009. Acanthamoeba interaction with extracellular matrix glycoproteins: Biological and biochemical characterization and role in cytotoxicity and invasiveness. Journal of Eukaryotic Microbiology 56 270-278.

Saimy, I.S. \& Mohamed Yusof, N.A. 2013. The need for better water policy and governance in Malaysia. Procedia Social and Behavioural Sciences 81: 371-375.

Samsudin, A.R., Haryono, A., Hamzah, U. \& Rafek, A.G. 2008. Salinity mapping of coastal groundwater aquifers using hydrogeochemical and geophysical methods: A case study from north Kelantan, Malaysia. Environmental Geology 55(8): 1737-1743.

Shamshuddin, J., Kang, M.S.K.E., Fauziah, C.I. \& Panhwar, Q.A. 2013. On the pyritization of the coastal sediments in the Malay Peninsula during the Holocene and its effects on soil. Malaysian Journal of Soil Science. https://core.ac.uk/ display/153810904.

Sheikhy Narany, T., Ramli, M.F., Aris, A.Z., Sulaiman, W.N.A. \& Fakharian, K. 2013. Spatial assessment of groundwater quality monitoring wells using indicator kriging and risk mapping, Amol-Babol plain, Iran. Water 6(1): 68-85.

Srebotnjak, T., Carr, G., de Sherbinin, A. \& Rickwood, C. 2012. A global water quality index and hot-deck imputation of missing data. Ecological Indicators 17: 108-119.

Sultan, K. \& Shazili, N.A. 2009. Rare earth elements in tropical surface water, soil, and sediments of the Terengganu River Basin, Malaysia. Journal of Rare Earth 27(6): 1072-1078.

Sultan, K., Shazili, N.A. \& Peiffer, S. 2011. Distribution of Pb, $\mathrm{As}, \mathrm{Cd}, \mathrm{Sn}$ and $\mathrm{Hg}$ in soil, sediment and surface water of the tropical river watershed, Terengganu (Malaysia). Journal of Hydro-Environment Research 5(3): 169-176.

Suresh, K., Smith, H.V. \& Tan, T.C. 2005. Viable Blastocystis Cysts in Scottish and Malaysian sewage samples. Applied and Environmental Microbiology 71(9): 5619-5620.

Tan, K.W. \& Mokhtar, M. 2009. An appropriate institutional framework towards integrated water resources management in the Pahang River basin, Malaysia. European Journal of Scientific Research 27(4): 536-547.

Tang, K.H.D. 2019. Climate change in Malaysia: Trends, contributors, impacts, mitigation and adaptations. Science of The Total Environment 650: 1858-1871.

Vishnu Radhan, R., Zainudin, Z., Sreekanth, G.B., Dhiman, R., Salleh, M.N. \& Vethamony, P. 2017. Temporal water quality response in an urban river: A case study in Peninsular Malaysia. Applied Water Science 7: 923-933. 
Wan Maznah, W.O. \& Mansor, M. 2002. Aquatic pollution assessment based on attached diatom communities in the Pinang River Basin, Malaysia. Hydrobiologia 487(1): 229241.

Weng, C.N. 2005. Sustainable management of rivers in Malaysia: Involving all stakeholders. International Journal of River Basin Management 3(3): 147-162.

Zaiha, A.N., Ismid, M.M. \& Azri, M.S., 2015. Effects of logging activities on ecological water quality indicators in the Berasau River, Johor, Malaysia. Environmental Monitoring and Assessment 187(8): 493.

Zhang, X., Xu, Z., Sun, X., Dong, W. \& Ballantine, D. 2013. Nitrate in shallow groundwater in typical agricultural and forest ecosystems in China, 2004-2010. Journal of Enviromental Sciences 25(5): 1007-1014.

Terfa E. Garba*, Mutari Lawal \& Nura A. Yelwa

Research Fellow

Department of Geology

University of Malaya

50603 Kuala Lumpur, Federal Territory

Malaysia

Reena L. Richard

Research Fellow

Department of Science and Technology University of Malaya 50603 Kuala Lumpur, Federal Territory

Malaysia
Nor Ezzawanis A. Thani

Research Fellow

Institute of Biological Sciences

University of Malaya

50603 Kuala Lumpur, Federal Territory

Malaysia

Mohamad Azlan A. Majid

Research Fellow

Tropical Infectious Diseases Research \& Education Centre

University of Malaya

50603 Kuala Lumpur, Federal Territory

Malaysia

Mutari Lawal \& Nura A. Yelwa

Research Fellow

Usman Danfodiyo University

P.M.B. 2346

Sokoto

Nigeria

*Corresponding author; email: garbater@hotmail.com

Received: 6 May 2020

Accepted: 21 November 2020 